\title{
IMPLEMENTASI ANTENA YAGI 5 ELEMEN SEBAGAI PENERIMA SIARAN TELEVISI DI BANDUNG KOTA
}

\section{IMPLEMENTATION OF 5 ELEMENT YAGI ANTENNA AS TELEVISION BROADCAST RECEIVER IN BANDUNG}

\author{
Deden Nur Rokhman ${ }^{1}$, Arsyad Ramadhan Darlis ${ }^{2}$, Lita Lidyawati ${ }^{3}$ \\ ${ }^{1,2,3}$ Teknik Elektro Peminatan Teknik Telekomunikasi Institut Teknologi Nasional Bandung \\ $\underline{{ }^{1} \text { Deden@itenas.ac.id, }}{ }^{2}$ arsyaddarlis@gmail.com, ${ }^{3}$ Litalidyawati3@gmail.com
}

\begin{abstract}
Abstrak
Antena Yagi merupakan salah satu antena yang dapat difungsikan sebagai piranti penerima gelombang elektromagnetik untuk menghasilkan kualitas siaran televisi yang baik. Penelitian ini bertujuan untuk merealisasikan antena yagi dengan rentang frekuensi 471,25 - 799,25 MHz dan jumlah elemen sebanyak 5. Software yang digunakan adalah QY4 untuk menentukan panjang dan spasi antar elemen antena tersebut dan dilanjutkan ke software MMANA-GAL untuk simulasi gain antena, beamwidth, pola radiasi, dan VSWR. Hasil dari simulasi tersebut dijadikan acuan perbandingan untuk proses pengujian antena. Hasil dari pengujian diperoleh Nilai VSWR yang didapat dengan cara perhitungan adalah 1,42 sedangkan nilai VSWR dari pengukuran adalah 1,627, yaitu pada frekuensi kerja 623,25 MHz. Nilai return loss pada frekuensi kerja 623,25 MHz sebesar $-12,439 \mathrm{~dB}$. Gain antena yang didapat dengan cara pengukuran dan perhitungan adalah 13,52 dB. Besarnya beamwidth (lebar pancaran) antena secara vertikal dan horizontal adalah $60^{\circ}$, besar daya terima antena dengan sampel dari salah satu pemancar TV di Bandung didapat sebesar $-66 \mathrm{dBW}$ atau $2,5 \times 10^{-7}$ Watt.
\end{abstract}

Kata kunci: Yagi, QY4, MMANA-GAL, 5 Elemen, Frekuensi Kerja 623,25 MHz

\begin{abstract}
Yagi antenna is one that can be used as a tool receiver of electromagnetic waves to produce a good quality television broadcasts. This study aims to realize the yagi antenna with frequency range from 471.25 to $799.25 \mathrm{MHz}$ and the number of elements as much as 5. Software used is QY4 to determine the length and spacing between the antenna elements and continued to MMANA-GAL software for simulation of antenna gain, beamwidth, radiation pattern, and VSWR. The results of the simulations used as a reference for comparison antenna testing process. The results obtained from testing the VSWR value obtained by calculation was 1.42 while the value of VSWR of measurement is 1.627 , which is the working frequency $623.25 \mathrm{MHz}$. Return loss at $623.25 \mathrm{MHz}$ operating frequency of $-12.439 \mathrm{~dB}$. Antenna gain is obtained by means of measurement and calculation is $13.52 \mathrm{~dB}$. The amount beamwidth (wide beam) antenna vertical and horizontal is $60^{\circ}$, the received power of the antenna with a sample of one of TV transmitters in Bandung obtained at $-66 \mathrm{dBW}$ or $2.5 \times 10-7$ Watt.
\end{abstract}

Keywords: Yagi, QY4, MMANA-GAL, 5 Elements, Operating Frequency $623.25 \mathrm{MHz}$ 


\section{PENDAHULUAN}

Kebutuhan informasi menjadi sangat penting sebagai salah satu sarana dalam menambah wawasan maupun untuk saling berinteraksi satu sama lain. Televisi merupakan sebuah perangkat yang berfungsi menyampaikan informasi. Untuk meningkatkan performansinya dalam menyampaikan informasi, televisi memerlukan sebuah antena yang berfungsi sebagai penerima gelombang elektromagnetik yang menjadi sarana perambatan informasinya. Untuk menghasilkan kualitas siaran televisi yang baik, maka diperlukan antena yang mampu menerima gelombang elektromagnetik dengan baik, diantaranya memiliki gain yang optimal, serta memiliki lebar pancaran (beamwidth) yang besar.

Antena yagi merupakan salah satu antena yang dapat difungsikan sebagai piranti penerima gelombang elektromagnetik untuk menghasilkan kualitas siaran televisi yang baik. Antena Yagi memiliki 3 komponen utama yaitu sebuah driven element yang merupakan pencatuan dari kabel antena, sebuah reflector yang berfungsi untuk memantulkan pancaran dari driven element, dan sebuah director yang mengarahkan pola pancar dari driven element. Namun guna mendapatkan penguatan (gain) yang optimal, perlu dilakukan modifikasi pada antena tersebut dengan mengubah susunan elemen, spasi antar elemen, jumlah elemen, bentuk, bahkan material elemen dan antena itu sendiri. Salah satu wujud dari hasil modifikasi antena yagi ialah antena yagi horn yang memiliki pola radiasi satu arah (unidirectional) dengan besar penguatan (gain) yang dapat diatur sesuai dengan jumlah elemen antenanya.

Perancangan antena untuk aplikasi penerimaan siaran televisi sebelumnya sudah banyak yang melakukan dan menelitinya dengan cara yang berbeda-beda, baik itu dari frekuensi yang digunakan, jumlah elemen yang digunakan, dan susunan elemen antena yang akan dirancang. Terdapat beberapa penelitian yang berhubungan dengan perancangan antena yagi yaitu sebagai berikut :

Pompi melakukan penelitian Perancangan dan Pembuatan Antena Horn Yagi 12 Elemen Menggunakan Software MMANA-GAL Untuk Mendapatkan Pola Radiasi Unidirectional. Dalam penelitiannya, jumlah elemen yang digunakan adalah 12 elemen, dengan susunan membentuk Horn dan frekuensi kerja yang digunakan adalah $594 \mathrm{MHz}$ [1].

Selain itu, penelitian mengenai antena yagi dengan bentuk horn juga dilakukan oleh Yenniwarti pada tahun 2013 dengan judul penelitian Perancangan dan Pembuatan Antena Horn Yagi 10 Elemen Untuk Aplikasi Penerimaan Siaran Televisi. Dalam penelitiannya, jumlah elemen yang digunakan adalah 10 elemen, dengan susunan membentuk Horn dan diameter elemen sebesar $9 \mathrm{~mm}$. sedangkan frekuensi kerja yang digunakan adalah $594 \mathrm{MHz}$ [2].

Kemudian Muhammad Soleh melakukan penelitian Perancangan Antena Yagi Uda Pada Frekuensi $600 \mathrm{MHz}$. Dalam penelitiannya di kota Semarang, beliau menggunakan frekuensi kerja $600 \mathrm{MHz}$ dengan jumlah elemen yang digunakan adalah 7 elemen [3].

Selain diaplikasikan untuk menerima siaran televisi, antena yagi juga dapat diaplikasikan untuk Wifi melakukan penelitian Perancangan dan Implementasi Antena Yagi 2,4 GHz Pada Aplikasi WiFi (Wireless Fidelity). Dalam penelitiannya di kota Bandung, beliau menggunakan frekuensi kerja 2,4 GHz dengan jumlah elemen yang digunakan adalah 15 elemen [4].

Pada beberapa penelitian sebelumnya, jumlah elemen yang digunakan dan bentuk antena berbeda - beda. Oleh karena itu pada penelitian ini akan dirancang sebuah antena yagi 5 elemen dengan rentang frekuensi 471,25 - 799,25 MHz yang dapat menjadi salah satu alternatif antena yang dapat digunakan dalam penerimaan siaran televisi di Bandung kota. 


\section{Software QY4}

QY4 atau Quick Yagi v4 adalah sebuah perangkat lunak yang digunakan untuk merancang sebuah antena yagi sesuai dengan kebutuhan dan desain yang diinginkan, QY4 mengonversi secara otomatis untuk panjang setiap elemen antena dan spasi antar elemennya dengan presisi.

Selain dapat di-download dengan gratis, salah satu kelebihan QY4 adalah data yang dibutuhkan untuk merancang sebuah antena yagi hanya terdiri dari frekuensi kerja antena yang akan dirancang, diameter elemen antena, dan jumlah elemen antena yang akan direalisasikan. Adapun kekurangan dari QY4 adalah aplikasi ini hanya bisa digunakan untuk merancang antena yagi saja, dan aplikasi ini hanya akan berfungsi pada perangkat PC atau laptop dengan sistem operasi WIN XP SP2/SP3 32 bit. Pada software QY4, data yang dimasukkan adalah frekuensi kerja antena, jumlah elemen, dan diameter elemen yang digunakan, sehingga didapat nilai-nilai untuk panjang dan spasi antar elemen antena tersebut. Kemudian nilai-nilai tersebut dilakukan pembulatan untuk selanjutnya dimasukkan ke software MMANA-GAL [5].

\section{Software MMANA-GAL}

Software MMANA-GAL pertama kali diciptakan oleh Macoto Mori, seorang amatir radio asal Jepang (10 Januari 1999). Versi MMANA yang dikenal selama ini, yaitu:
a. MMANA Ver 0.5 dan Ver 0.72
b. MMANA Ver 2.03 (12 -12- 2005)
c. MMANA-GAL (20 Mei 2006)

MMANA-GAL adalah salah satu software yang digunakan untuk merancang sebuah antena baik itu dalam bentuk yagi, yagi horn, twin loop, delta, dan bentuk lainnya lagi. Salah satu kekurangan dari aplikasi ini adalah perancang harus mencoba berulang kali untuk mendapatkan rancangan antena yang diinginkan, karena perancang harus menghitung panjang elemen dan jarak antar elemen secara manual. Pada software ini, data yang dimasukkan adalah frekuensi kerja antena, panjang dan spasi setiap elemen yang telah didapat dari software QY4. Sehingga didapat nilai gain antena, beamwidth, pola radiasi, dan VSWR.

\section{METODOLOGI}

\subsection{Perancangan Antena Yagi}

Pada bab ini menjelaskan tentang perancangan dan realisasi antena yagi. Berikut ini adalah flowchart uji performasi penelitian ini:

Gambar 1 menjelaskan tentang flowchart penelitian ini. Pertama, penulis merancang antena yagi dengan frekuensi tengah 635,250 MHz dan jumlah elemen sebanyak 5 dengan diameter setiap elemen $8 \mathrm{~mm}$. Selanjutnya data tersebut dimasukkan dalam simulasi menggunakan software QY4 dan dilanjutkan ke software MMANA-GAL. Setelah mendapatkan hasil dari simulasi, dilanjutkan dengan merealisasikan hasil simulasi dan kemudian dilakukan pengujian. Ketika hasil pengujian dikatakan tidak berhasil, maka kembali ke realisasi pembuatan antena. Tetapi, apabila hasil pengujian dikatakan berhasil, maka proses dilanjutkan ke analisis dan kesimpulan dari data yang diperoleh dari pengujian. 


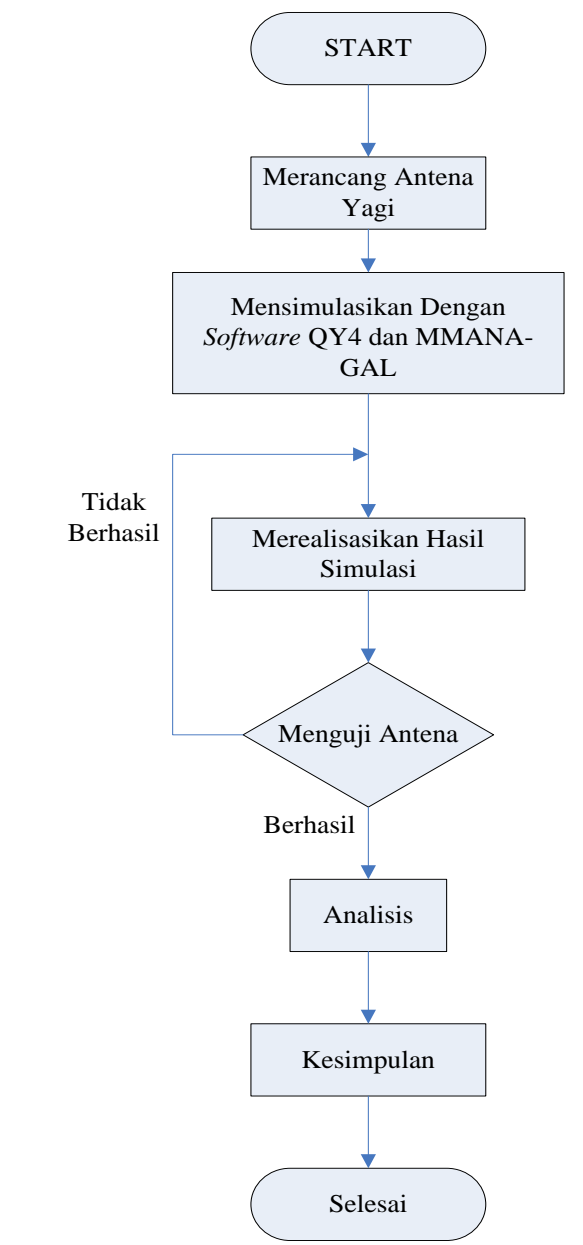

Gambar 1. Flowchart Perancangan Antena

\subsection{Realisasi Antena [6,7,8]}

Data yang didapat dari software digunakan untuk merealisasikan antena. Tabel 1 menunjukan data-data yang didapat dari software:

Tabel 1. Panjang dan Jarak Setiap Elemen

\begin{tabular}{|c|c|c|c|c|c|c|}
\hline \multirow{2}{*}{ Elemen } & \multicolumn{3}{|c|}{ Hasil Simulasi } & \multicolumn{4}{c|}{ Hasil Pembulatan } \\
\cline { 2 - 7 } & Panjang Elemen (m) & \multirow{2}{*}{ Spasi (m) } & \multicolumn{2}{|c|}{ Panjang Elemen } & \multicolumn{2}{c|}{ Spasi } \\
\cline { 4 - 7 } & & & $(\mathbf{c m})$ & $(\mathbf{m})$ & $\mathbf{( c m})$ & $(\mathbf{m})$ \\
\hline Reflector & 0.240346 & & 24 & 0,24 & & \\
\hline & & 0.084704 & & & 8.5 & 0,085 \\
\hline Driven & 0.222836 & & 22 & 0,22 & & \\
\hline & & 0.054621 & & & 5.5 & 0,055 \\
\hline Director 1 & 0.212012 & & 21 & 0,21 & & \\
\hline Director 2 & 0.200061 & 0.073826 & & & 7.4 & 0,074 \\
\hline & & & 20 & 0,2 & & \\
\hline Director 3 & 0.189352 & 0.099178 & & & 10 & 0,1 \\
\hline
\end{tabular}

Bahan yang digunakan untuk pembuatan antena ini adalah alumunium, karena memiliki konduktivitas yang bagus dan untuk menghemat biaya. Sedangkan untuk alat dan bahan yang digunakan dalam merealisasikan antena adalah sebagai berikut: 
Alat yang digunakan dalam perancangan antena:

1. Bor Listrik

2. Penggaris dan Pensil

3. Clapper

4. Tube Cutter

5. Gergaji besi

6. Pisau dan gunting

7. Tang

Bahan-bahan yang digunakan:

1. Pipa alumunium persegi dengan panjang tiap sisinya $1,4 \mathrm{~cm}$

2. Pipa alumunium silinder berdiameter $8 \mathrm{~mm}$

3. Paku Rivet

4. Kabel Coaxial RG-59 (75 Ohm)

5. Konektor $N$-Female

6. Lem lilin

Gambar 2 merupakan hasil realisasi antena pada penelitian ini

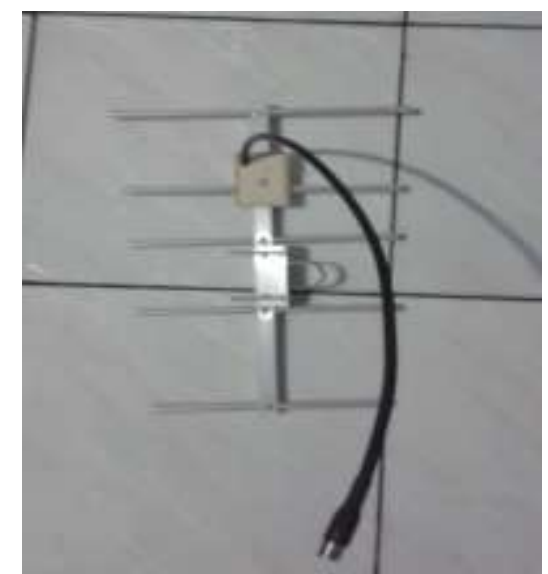

Gambar 2. Antena Yagi Hasil Perancangan

Pada Gambar 2 menunjukkan antena yagi hasil dari realisasi, terlihat jumlah elemen sebanyak 5, sesuai dengan perancangan.

\section{PENGUJIAN dan ANALISIS}

\subsection{Pengukuran Impedansi Input dan Menghitung VSWR [9]}

Untuk mengetahui nilai VSWR, maka mencari nilai impedansi beban terlebih dahulu dengan menggunakan Advantest R3770 Network Analyzer yang dihubungkan dengan kabel Coaxial RG-59 seperti pada Gambar 3.

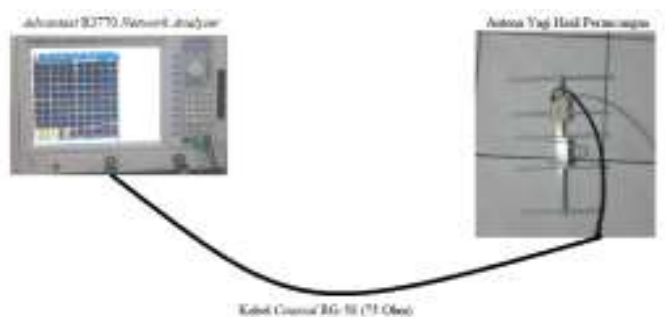

Gambar 3. Pengukuran Antena dengan Advantest R3770 Network Analyzer

Sebelum dilakukan pengukuran, terlebih dahulu ditentukan batasan frekuensi pada alat ukur Advantest R3770 network Analyzer dengan frekuensi 471,250 - 799,250 MHz, kemudian 
memilih mode impedance input. Sehingga didapat nilai-nilai impedansinya seperti terlihat pada Gambar 4.

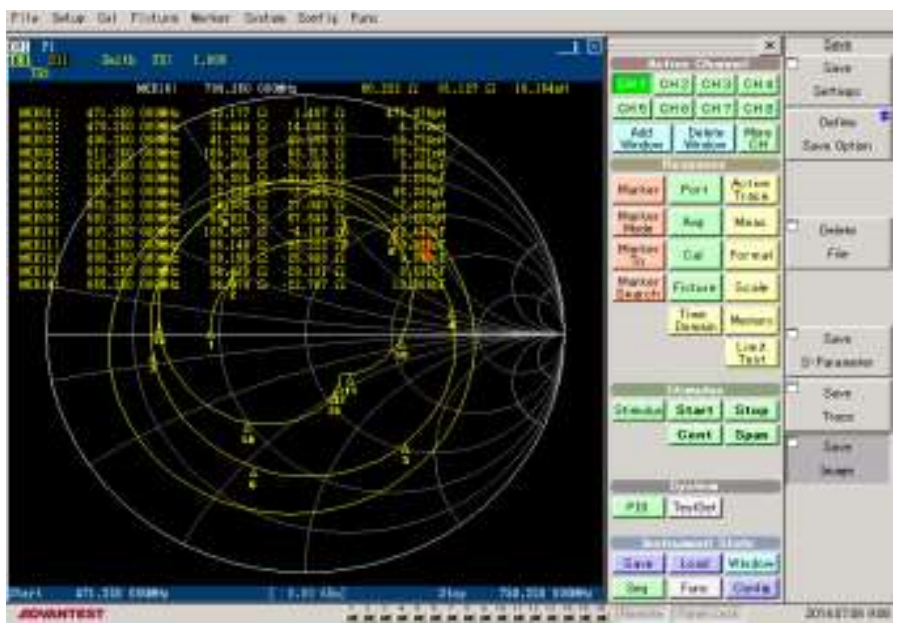

Gambar 4. Nilai-nilai Impedansi Input

Dari hasil pengukuran, pada saat frekuensi kerja $623,25 \mathrm{MHz}$ nilai impedansinya adalah $66,143+\mathrm{j} 23,222 \Omega$, maka dengan menggunakan rumus pada persamaan 1 dan persamaan 2, nilai VSWR dapat dicari dengan menghitung nilai koefisien refleksinya $(\Gamma)$ terlebih dahulu, dimana impedansi karakteristiknya $\left(\mathrm{Z}_{\mathrm{o}}\right)$ adalah $75 \Omega$, sehingga nilai VSWR-nya adalah :

$$
\begin{array}{ll}
\Gamma & =\frac{V_{o}^{-}}{V_{o}^{+}}=\frac{Z_{l}-Z_{o}}{Z_{l}+Z_{o}}=\frac{(66,143+\mathrm{j} 23,222)-75 \Omega}{(66,143+\mathrm{j} 23,222)+75 \Omega} \\
\Gamma & =\frac{-8,857+j 23,222}{141,143+j 23,222}=\frac{24,854 \angle-69,12^{\circ}}{143,04 \angle 9,34^{\circ}} \\
\Gamma & =0,174 \angle-78,46^{\circ}=0,035-\mathrm{j} 0,17 \\
|\Gamma| & =\sqrt{0,035^{2}+0,17^{2}}=0,174
\end{array}
$$

Sehingga secara perhitungan teoritis, didapat nilai VSWR:

$$
S=\frac{1+|\Gamma|}{1-|\Gamma|}=\frac{1+0.174}{1-0.174}=1.42
$$

Sedangkan nilai VSWR yang didapat secara pengukuran, dapat dilihat pada Gambar 5:

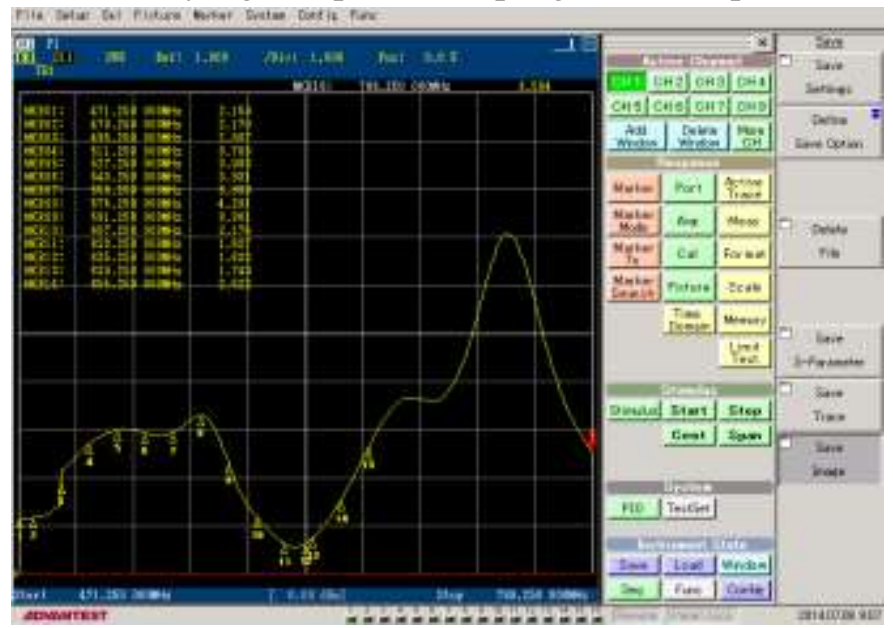

Gambar 5. Hasil Pengukuran VSWR Antena 
Pada Gambar 5, didapat nilai VSWR terkecil berada pada frekuensi 623,25 MHz yaitu sebesar 1,627, sedangkan untuk frekuensi tengah $635,25 \mathrm{MHz}$ adalah 1,632, nilai VSWR tersebut tidak jauh berbeda dengan nilai VSWR hasil perhitungan secara teoritis, karena nilai pada perhitungan secara teoritis merupakan nilai dari persamaan yang menjadi ketentuan secara umum, dimana didalamnya telah terjadi pembulatan dan penyederhanaan. Perbedaan nilai VSWR menunjukan bahwa antena yang telah diimplementasikan ini memiliki daya pantul yang lebih besar dibandingkan daya kirimnya. Tetapi nilai pengukuran VSWR tersebut masih dikatakan layak untuk digunakan, karena secara teoritis sebuah antena masih dikatakan layak untuk digunakan jika nilai VSWR-nya dibawah 2.

\subsection{Pengukuran Return Loss (RL) $[10,11]$}

Pengukuran nilai return loss (RL) pada alat ukur Advantest R3770 network Analyzer, dapat dilakukan dengan hanya mengganti mode pengukuran ke mode return loss. Hasil pengukuran return loss antena yagi pada frekuensi $471,250-799,250 \mathrm{MHz}$ dapat dilihat pada Gambar 6 sebagai berikut:

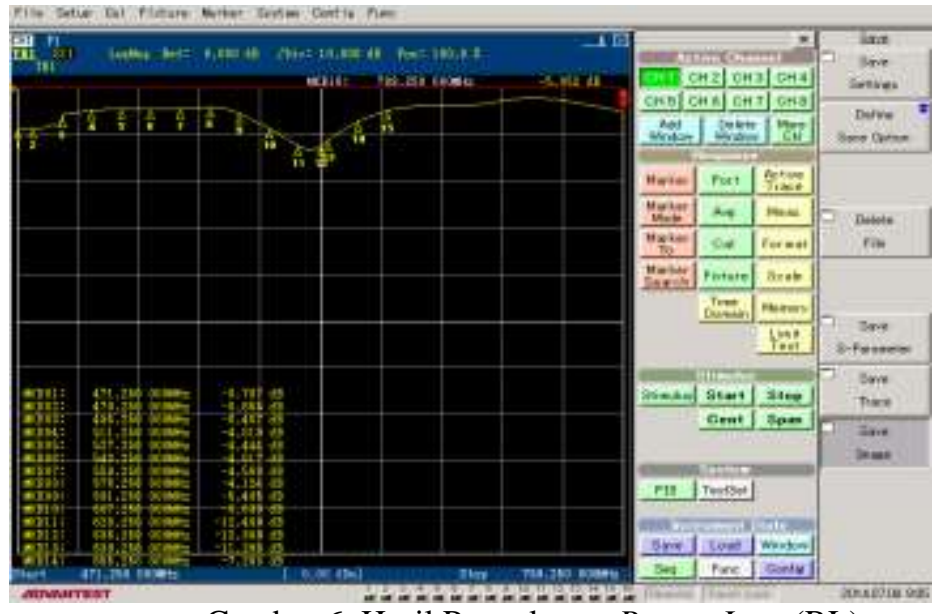

Gambar 6. Hasil Pengukuran Return Loss (RL)

Dari hasil pengukuran pada Gambar 6, didapat nilai Return Loss minimum (paling baik) pada frekuensi $623,25 \mathrm{MHz}$ yaitu dengan nilai RL 12,439 dB, sedangkan nilai RL pada frekuensi tengah 635,25 MHz adalah $12.389 \mathrm{~dB}$. Dapat dianalisis dari hasil pengujian tersebut, bahwa frekuensi kerja berada pada frekuensi $623,25 \mathrm{MHz}$. Hal tersebut dilihat dari nilai VSWR terkecil yaitu 1,627 dan Return Loss minimum yaitu 12,439 dB.

\subsection{Pengukuran Gain Antena Yagi [10,11]}

Pada pengukuran ini, alat bantu yang digunakan untuk pengujian antena adalah kabel Coaxial RG-59 (75 Ohm), Spectrum Analyzer 8593A, dan antena referensi DRG horn dengan gain $8 \mathrm{~dB}$. Antena referensi dan antena yagi diposisikan saling berhadapan yaitu dengan mengarahkan director antena yagi ke antena horn, dan kedua antena berada pada ketinggian 2 meter diatas permukaan lantai dan jarak antara kedua antena adalah lebih kurang 2 meter, dikarenakan pengujian antena dilakukan dalam ruang chamber yang luasnya ruangan terbatas. Namun lebih efektif untuk pengujian antena karena ruang chamber tidak terpengaruh oleh sinyal lain dari luar ruangan.

Kedua antena dihubungkan ke Spectrum Analyzer 8593A menggunakan kabel Coaxial RG59 dengan impedansi 75 Ohm dimana antena referensi horn berfungsi sebagai pemancar $\left(\mathrm{T}_{\mathrm{X}}\right)$ 
dengan daya pancar $\left(\mathrm{P}_{\mathrm{T}}\right)=-32 \mathrm{dBm}$ dan gain $=8 \mathrm{~dB}$. Gambar 7 menunjukkan instalasi pengujian gain antena yagi dengan alat bantu Spectrum Analyzer 8593A.

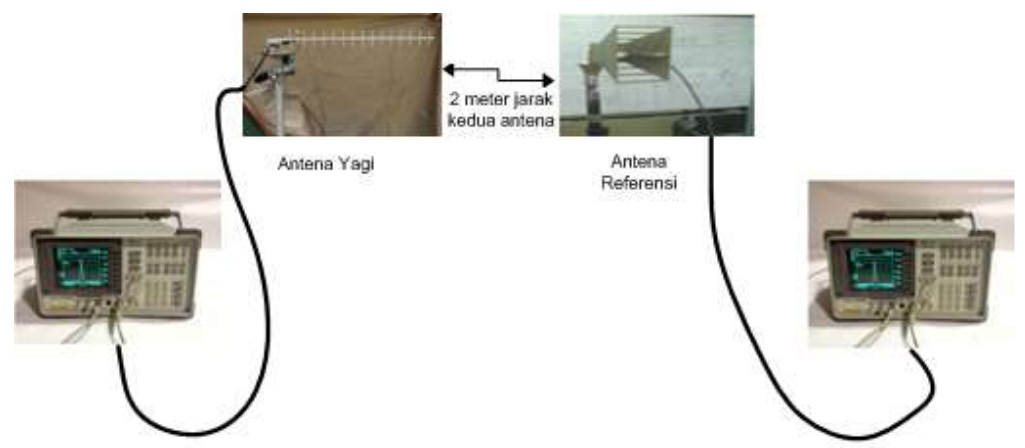

Gambar 7.Pengukuran Gain Antena Yagi

Dari pengukuran tersebut, didapat nilai hasil pengukuran menggunakan Spectrum Analyzer 8593A sebesar $-45 \mathrm{dBm}$. Nilai tersebut adalah nilai daya terima $\left(\mathrm{P}_{\mathrm{R}}\right)$ antena yagi dalam pengujian tersebut dan dalam ruangan bebas, sehingga besarnya gain antena yagi dapat dicari dengan menggunakan rumus pada persamaan 3 dan 4 yaitu dengan mencari nilai redaman ruang bebas terlebih dahulu.

$\mathrm{a}_{\mathrm{o}} \quad=32,45+20 \log \mathrm{d}(\mathrm{Km})+20 \log \mathrm{f}(\mathrm{MHz})$

(3)

$=32,45+20 \log (0,002)+20 \log (623,25)$

$=34,36 \mathrm{~dB}$

$\mathrm{P}_{\mathrm{T}} \quad=-32 \mathrm{dBm}$

$\mathrm{P}_{\mathrm{R}} \quad=-45 \mathrm{dBm}$

$\mathrm{G}_{\mathrm{T}} \quad=8 \mathrm{~dB}$

$\mathrm{a}_{\mathrm{o}} \quad=34,52 \mathrm{~dB}$

Sehingga nilai gain-nya adalah

$$
\begin{aligned}
\mathrm{P}_{\mathrm{T}}-\mathrm{P}_{\mathrm{R}} & =\mathrm{a}_{\mathrm{o}}-\left(\mathrm{G}_{\mathrm{T}}+\mathrm{G}_{\mathrm{R}}\right) \\
& (4) \\
\mathrm{G}_{\mathrm{R}} & =\mathrm{a}_{\mathrm{o}}+\mathrm{P}_{\mathrm{R}}-\mathrm{P}_{\mathrm{T}}-\mathrm{G}_{\mathrm{T}} \\
& =34,36-(-32)-45-8 \\
& =13,36 \mathrm{~dB}
\end{aligned}
$$

Dengan jumlah elemen sebanyak 5 elemen, nilai gain sebesar 13,36 dB dapat dikatakan baik jika dibandingkan dengan antena-antena yang didapat pada referensi penulis, yaitu rata-rata nilai gainnya dibawah $10 \mathrm{~dB}$ dengan jumlah elemen yang lebih banyak.

\subsection{Pola Radiasi [8]}

Pengukuran ini bertujuan untuk mengetahui berapa besar level daya yang diterima oleh antena yagi ketika antena diputar beberapa derajat sampai kembali ke posisi semula. Proses pengukuran dilakukan secara manual yaitu diukur daya penerimaan yang diterima di spektrum analyzer dari arah $0^{\circ}$ sampai $360^{\circ}$ pada kelipatan $30^{\circ}$. Data hasil pengukuran ditabelkan dan digunakan untuk menggambarkan pola radiasi dengan menggunakan Microsoft excel.

Pengukuran antena dilakukan sama seperti ketika pengukuran untuk menghitung gain, yaitu ditunjukkan pada Gambar 7 dimana antena referensi dan antena yagi diposisikan saling 
berhadapan dengan director antena yagi mengarah ke antena horn, dan kedua antena berada pada ketinggian 2 meter di atas permukaan lantai dan jarak antara kedua antena adalah lebih kurang 2 meter.

Kedua antena dihubungkan ke Spectrum Analyzer 8593A menggunakan kabel Coaxial RG59 dengan impedansi 75 Ohm dimana antena referensi horn berfungsi sebagai pemancar $\left(\mathrm{T}_{\mathrm{X}}\right)$. Hasil dari pengukuran ditabelkan sebagai berikut.

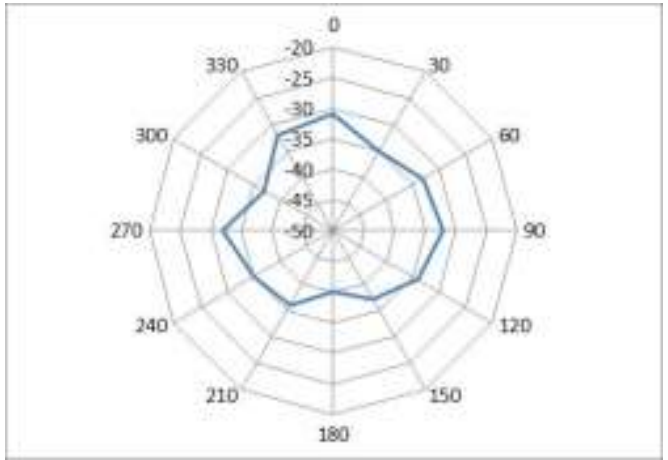

Gambar 8. Pola Radiasi Secara Vertikal

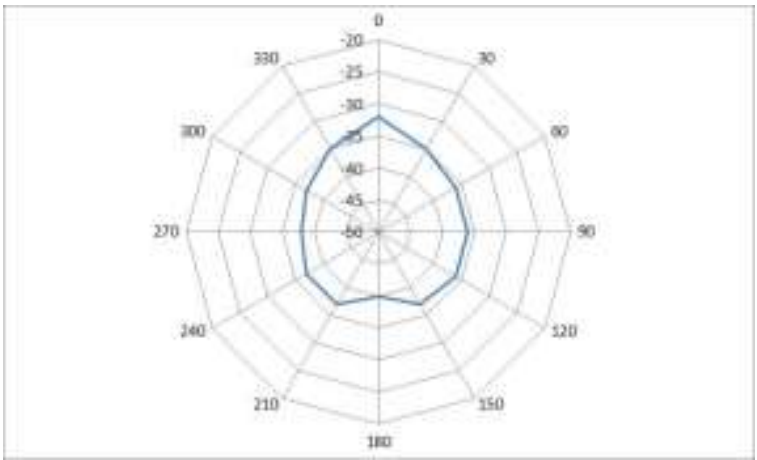

Gambar 9. Pola Radiasi Secara Horizontal

Pola radiasi antena hasil perancangan yang terlihat pada Gambar 8 dan Gambar 9, menunjukkan bahwa pola radiasi tersebut merupakan pola radiasi dari antena yagi. Namun hasil tersebut berbeda dengan pola radiasi antena pada saat simulasi, dikarenakan pada saat pengukuran menggunakan skala $30^{\circ}$, sedangkan pada simulasi secara otomatis aplikasi menggunakan skala $1^{\circ}$ sehingga pola yang didapat lebih presisi.

\subsection{Menentukan Beamwidth [8]}

Lebar berkas (beamwidth) merupakan lebar cakupan pancaran antena maupun penerima antena, lebar berkas dinyatakan dalam besaran sudut. Beamwidth antena merupakan besarnya lebar pancaran (beam) yang didapat dari titik potong antara pola radiasi antena dengan pola lingkaran dari daya terima maksimum dikurangi $3 \mathrm{~dB}$. Menentukan beamwidth menggunakan dua tahap yaitu secara vertikal dan horizontal.

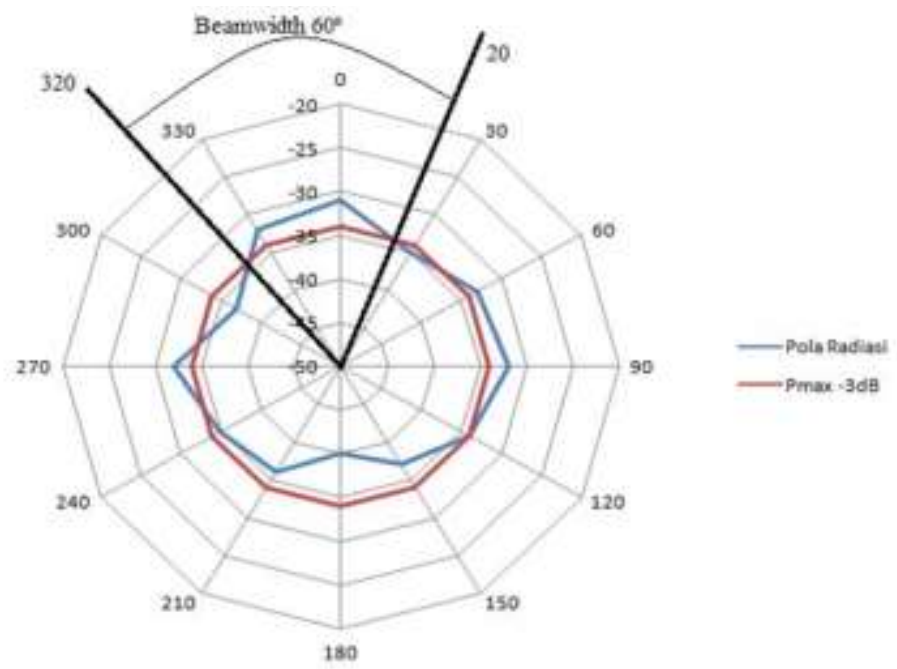

Gambar 10. Beamwidth Vertikal 
Beamwidth pada posisi antenna vertikal nilainya mendekati dari hasil simulasi, yaitu sebesar $60^{\circ}$ sedangkan dalam simulasi besar beamwidth-nya adalah $74,2^{\circ}$

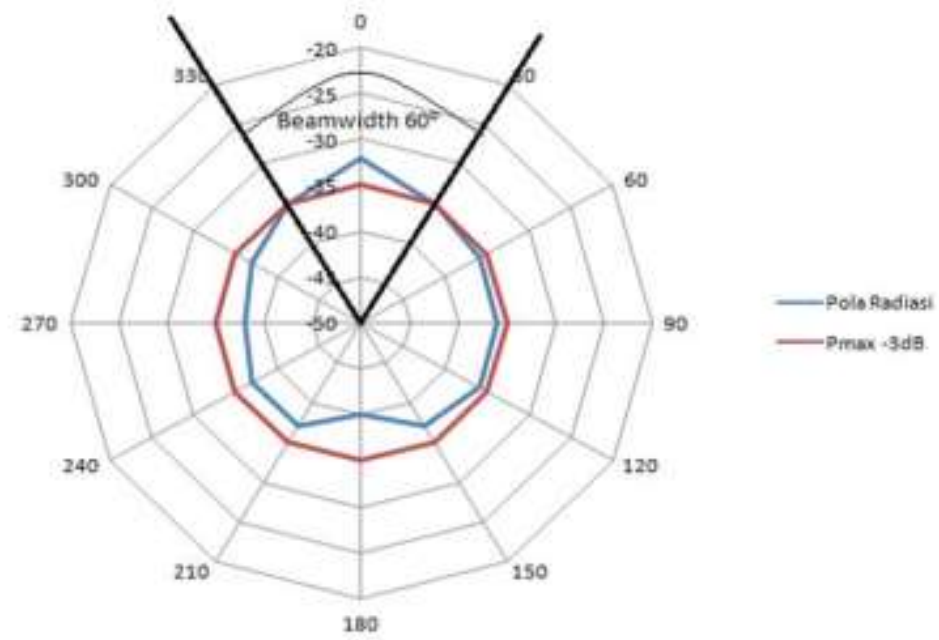

Gambar 11. Beamwidth Horizontal

Beamwidth pada posisi antenna horizontall nilainya mendekati dari hasil simulasi, yaitu sebesar $60^{\circ}$ sedangkan dalam simulasi besar beamwidth-nya adalah $58,2^{\circ}$.

\subsection{Perhitungan Daya Terima Antena Yagi $\left(\mathbf{P}_{\mathbf{R}}\right)$}

Besarnya daya terima antena dipengaruhi oleh besarnya daya pancar stasiun pemancar siaran televisi di suatu tempat tertentu pada jarak tertentu. Semakin tinggi daya pancar semakin besar level kuat medan penerimaan siaran televisi. Namun besarnya penerimaan siaran televisi tidak hanya dipengaruhi oleh besarnya daya pancar.Besarnya daya terima antena yagi dipengaruhi antara lain oleh besarnya frekuensi, ketinggian antena pemancar dan antena penerima, profil antara lokasi pemancar dengan lokasi penerima, juga redaman kabel yang digunakan.

Dalam perhitungan ini, penulis mengambil satu sampel stasiun pemancar televisi yang ada di wilayah Bandung. Dengan data yang didapat sebagai berikut :

Tabel 4. Data Stasiun Pemancar TRANS TV Bandung

\begin{tabular}{|c|c|c|}
\hline \multicolumn{2}{|c|}{ Stasiun Pemancar TRANS TV Bandung } & Keterangan \\
\hline Tinggi Antena & 15 meter & Posisi antena dari permukaan tanah \\
\hline Besar Daya Pancar Antena & $150 \mathrm{Watt}$ & \\
\hline Gain Antea & $18 \mathrm{~dB}$ & Pembulatan \\
\hline Jarak Pemancar - Penerima (d) & 20 kilometer & Kabel Heliax D10/20 $(0,25 \mathrm{~dB} /$ meter $)$ \\
\hline Feeder Loss Pemancar & $3,75 \mathrm{~dB}$ & \\
\hline
\end{tabular}

Dengan data pada Tabel 4 diatas dan dengan menggunakan persamaan 3 dan 5 dibawah ini, maka besarnya daya terima antena yagi dapat dihitung sebagai berikut :

$$
\mathrm{a}_{\mathrm{o}} \quad=32,45+20 \log \mathrm{d}(\mathrm{Km})+20 \log \mathrm{f}(\mathrm{MHz})
$$




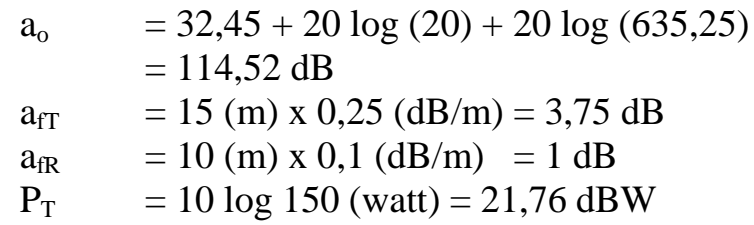

Sehingga didapat nilai $\mathrm{P}_{\mathrm{R}}$ sebagai berikut :

$$
\begin{aligned}
P_{T}-P_{R} & =a_{o}-\left(G_{T}+G_{R}\right)+a_{f T}+a_{f R} \\
P_{R} & =-\left[a_{o}-\left(G_{T}+G_{R}\right)+a_{f T}+a_{f R}-P_{T}\right] \\
& =-[114,52-(18+13,52)+3,75+1-21,75] \\
& =-66 \mathrm{dBW} \\
& =2,5 \times 10^{-7} \text { Watt }
\end{aligned}
$$

Besarnya level kuat medan penerimaan siaran televisi untuk frekuensi tertentu, CCIR/ITU$\mathrm{R}$ memberikan rekomendasi yang dapat digunakan sebagai referensi, namun di setiap negara memiliki kebijaksanaan tersendiri tentang kualitas penerimaan siaran televisi yang dikaitkan dengan persyaratan kuat medan minimum. Sampai saat ini di Indonesia belum ada kebijaksanaan khusus mengenai persyaratan minimum kuat medan pancaran siaran televisi yang harus dipenuhi untuk suatu penerimaan siaran televisi yang dianggap baik.

\section{KESIMPULAN dan SARAN}

\subsection{Kesimpulan}

Dari hasil pengujian parameter-parameter antena baik secara perhitungan teoritis dan pengukuran dengan alat bantu, dapat disimpulkan sebagai berikut:

1. Pada frekuensi kerja $623,25 \mathrm{MHz}$, nilai VSWR yang didapat dengan cara perhitungan adalah 1,42 dan nilai VSWR dari pengukuran adalah 1,627.

2. Nilai return loss pada frekuensi kerja $623,25 \mathrm{MHz}$ adalah $12,439 \mathrm{~dB}$.

3. Gain antena yang didapat dengan cara pengukuran dan perhitungan adalah $13,52 \mathrm{~dB}$

4. Besarnya beamwidth (lebar pancaran) antena secara vertikal dan horizontal adalah $60^{\circ}$

5. Besar daya terima antena dengan contoh dari salah satu pemancar TV di Bandung didapat sebesar $-66 \mathrm{dBW}$ atau $2,5 \times 10^{-7}$ Watt

\subsection{Saran}

Adapun saran yang dapat diberikan untuk meningkatkan kinerja dari antena yang diimplementasikan adalah :

1. Jumlah elemen dapat diperbanyak guna meningkatkan direktifitas dari antena yang akan berpengaruh kepada beamwidth

2. Keakuratan dalam perancangan antena harus ditingkatkan agar dapat meningkatkan VSWR sehingga dapat mendekati nilai yag ditunjukan pada teori

\section{Daftar Pustaka:}

[1] Orlando, Pompi. 2009. Perancangan dan Pembuatan Antena Horn Yagi 12 Elemen Menggunakan Software MMANA-GAL Untuk Mendapatkan Pola Radiasi Unidirectional, Padang : Universitas Andalas.

[2] Rafsyam, Yenniwarti. 2013. Perancangan dan Pembuatan Antena Horn Yagi 10 Elemen Untuk Aplikasi Penerimaan Siaran Televisi. Depok : Politeknik Negeri Jakarta.

[3] Soleh, Muhammad. 2012. Perancangan Antena Yagi Uda Pada Frekuensi $600 \mathrm{MHz}$, Semarang : Teknik Elektro Undip. 
[4] Pratama, Budi. 2013. Perancangan Dan Implementasi Antena Yagi 2.4 GHz pada Aplikasi WIFI (Wireless Fidelity), Jurnal Elkomika Volume 1 Nomor 1 Januari - Juni 2013 pp $35-47$.

[5] Warren L, Strutzman, Gary A. Thiele. 2012. Antenna Theory and Design 3rd Edition, Virginia : John Wiley \& Sons inc.

[6] Soetamso. 2003. Diktat Kuliah Pengembangan Teknik Antena Menuju Kompetensi Rekayasa. Bandung : STT Telkom.

[7] Trisapto, Poernomo. 1999. Diktat Kuliah Teknik Elektro Saluran Transmisi. Bandung : Teknik Elektro Institut Teknologi Nasional Bandung.

[8] Darlis, Arsyad Ramadhan. 2013. Perancangan dan Realisasi Sistem Remote Tilting Antenna untuk aplikasi Base Transceiver Station (BTS). Jurnal Elkomika Volume 1 Nomor 2 Juli Desember 2013 pp. $97-105$

[9] Trisapto, Poernomo. 1996. Diktat Kuliah Perencanaan Sistem Radio. Bandung : Teknik Elektro Institut Teknologi Nasional Bandung.

[10] Bima. 2013. Implementasi Reflector Antena Wajanbolik pada Layanan EVDO (Evolution Data Optimized). Jurnal Elkomika Volume 1 Nomor 1 Januari - Juni 2013 pp 1 - 12.

[11] Yurandi, Nugraha. 2013. Perancangan dan Implementasi Reflector Antena Wifi dengan Frekuensi 2,4 GHz. Jurnal Reka Elkomika Volume 1 Nomor 3 Februari 2013 pp. 233 -244. 